rollierender Querschnittsbefragungen kombiniert. In den letzten sechs Wochen vor der Wahl wurden Befragte dabei via Internet - insgesamt drei Mal befragt; gleichzeitig ist diese heiße Phase des Wahlkampfs durch tägliche Interviews begleitet worden, um Veränderungs- und Kristallisationsprozesse in der öffentlichen Meinung so detailliert wie möglich untersuchen zu können.

Wie das aussehen kann, zeigt folgendes Beispiel. Dargestellt sind die Einstellungen der Bevölkerung in Baden-Württemberg zur Zukunft der Atomenergie. Deutlich erkennbar wird die Verschiebung um rund einen Skalenpunkt (hin zu einer atomkritischeren Haltung) im Nachgang der Katastrophe von Fukushima. Ohne Zweifel ein extremes Ereignis - aber ohne die explizite Berücksichtigung von Dynamik greifen Wahlstudien in diesen politisch turbulenten Zeiten jedenfalls zu kurz. (TF)

Thorsten Faas, Uni-Mannheim, Mannheim, Germany. E-Mail: thorsten.faas@uni-mannheim.de

Roberto Heinrich, infratest-dimap, Berlin, Germany. E-Mail: Roberto.Heinrich@infratest-dimap.de

\section{Governance/ Administration-Corner}

\section{TRENDS}

\section{Corporate Venture Capital and Policy Entrepreneurship:} Bridging the Gap for Social Entrepreneurs

Corporate Venture Capital (CVC) refers to venture capital usually invested by large corporations in promising start-ups and emerging companies. While an independent venture capitalist fund's sole objective is making financial returns, a Corporate Venture Capitalist typically has a combination of financial and strategic objectives. The reasons for CVC investment are often multifold and not only profit-oriented.

Policy makers in highly industrialized countries are increasingly interested in the role of CVC due to reservations of traditional VCs to invest in risky new ventures after the financial crises, in 2008, and the Stock Market Crash, 2000 to 2002. With the High-Tech Gründerfonds, the German government responded to the lack of venture capital, in Germany. The High Tech-Gründerfond bundles state and private capital to be invested in innovative start-ups and is, therefore, a special form of corporate venture capital. The German government joined together with the KfW banking group and the industrial enterprises BASF, Deutsche Telekom and Siemens to initiate the High-Tech Gründerfonds, in 2005. The amount of capital provided by the fund's investors totals $€ 272$ million. Since its inception in August 2005, more than 2,100 inquiries about financial aid have been submitted. As of July 2009, the fund has pledged aid in 197 cases and has
156 companies in its portfolio. Over $€ 90$ million in capital has been contractually pledged to these companies.

Recently, the High-Tech Gründerfonds started investing in social enterprises which indicates an increasing acceptance and importance of social enterprises for at least two major reasons: they contribute to economic growth and social development, and they have the potential to grow and can turn to profitable, economically successfully ventures.

\section{Seed Capital for Social Entrepreneurs}

In October 2010, the High-Tech Gründerfonds, Seedfonds Bayern and Extorel announced that they are investing in Altruja.de. The online fundraising company was established in Munich, in March 2010. Organizations such as UNESCO, Aktion Deutschland Hilft as well as many regional charities are already managing their fundraising campaigns with the help of Altruja's tool. Altruja provides a social fundraising software which can easily and quickly be integrated into any website. Using this software and Web 2.0, aid organizations and other fundraising institutions like universities, associations, schools, political initiatives etc. can reach new supporters as well as contributors and thereby exponentially increase the amount of funds they raise.

\section{Social Entrepreneurs Running IPO: The Future of the Microlending Industry?}

With the initial public offering (IPO) of India's largest microlender SKS Microfinance Ltd., a social enterprise is taking the profit-maximizing route different from most non-profit organizations and social enterprises. The high-growth, profit-oriented model of lending to micro entrepreneurs is promoted by the company's founder, Vikram Akula, a multi-millionaire who started the company as non-profit SKS Society, in 1998. In 2005, SKS decided to pursue an aggressive growth plan and transformed into a Non-Banking Financial Company named SKS Microfinance regulated by the Reserve Bank of India. Its mission is to empower the poor by providing collateral-free loans to generate income. SKS Microfinance has 5.8 million clients (2010) in 1,627 branches in 19 states across India and total assets worth $\$ 897.9$ million (September 2009). The borrowers are all women and take loans to initiate a wide range of activities, such as livestock, agriculture, trade, and production.

On July 28, 2010, SKS Microfinance entered the Bombay Stock Exchange, offering its shares to the general public. It was expected that the Indian company will raise up to $\$ 354$ million in this initial public offering. Vikram Akula claimed that IPO is essential to raise additional funds which may allow SKS to support an even larger number of poor people. However, others, most notably Nobel Peace Prize winner Muhammad Yunus, expressed doubts that Akula will be able to harmonize between SKS's social mission and the demands of a traditional profit-maximizing business. The main obligation of any public company is to make dividends for its shareholders, while the main obligation of a MFI is to serve 
the poor. Yunus is concerned that SKS will have to put its shareholders' interests above the ones of the poor.

The fact that some are getting rich while lending to the poor, triggered off a heated debate about the future of the microlending industry. Yunus underlined that that there is no room for giant IPOs with profit-making strategies in the microlending sector which originally aimed at pursuing the mission to reduce poverty. Akula, on the contrary, claims that SKS is not facing a moral dilemma.

\section{Further Reading}

\section{On Seed Capital:}

Altruja website: http://www.altruja.de (accessed 16 March 2011).

Change.org website. Venture Capital. http://socialentrepreneurship.change.org/blog/category/venture_capital (accessed 16 March 2011).

High-Tech Gründerfonds website: http://www.high-tech-gruenderfonds.de (accessed 16 March 2011).

Reis, N. (2010). Seed capital for interactive fundraising tool. http://www.en.high-tech-gruenderfonds.de/2010/10/ seed-capital-for-interactive-fundraising-tool/ (accessed 16 March 2011).

\section{On IPO:}

Barta, P, \& Bellman, E. (2010). Microlenders Make Millions With SKS IPO. http://blogs.wsj.com/indiarealtime/2010/07/28/microlenders-make-millions-with-sksipo/ (accessed 16 March 2011).

Bellman, E. (2010) IPO Pits Profit vs. Altruism. http://online. wsj.com/article/SB10001424052748703609004575355 460120599280.html (accessed 16 March 2011).

Kinetz, E. (2010). SKS Launches India's First Microfinance IPO. http://abcnews.go.com/Business/wireStory?id= 11270209 (accessed 16 March 2011).

\section{Related Events}

\section{Popular Events about Social Entrepreneurship}

Regularly updates event calendar, see http://events.linkedin. com/social-entrepreneurship.

World Economic Forum on Latin America 2011 Rio de Janeiro, Brazil 27-29 April. Documentation is available at: http://www.schwabfound.org/sf/Events/ WorldEconomicForumEvents/index.htm.

Heike Grimm, Uni-Erfurt, Erfurt, Germany.

E-Mail: heike.grimm@uni-erfurt.de

\section{Think-Tank-Corner}

\section{TRENDS}

\section{Wurde auch Zeit - ein deutscher Think Tank auf der BILD- Titelseite!}

Es geschieht ausgesprochen selten, dass Neuigkeiten aus einer Denkfabrik auf der Titelseite einer großen deutschen Boulevardzeitung erscheinen. Bei dem am 2. Februar 2011 angekündigten Rückzug des Präsidenten des Deutschen Instituts für Wirtschaftsforschung (DIW), Klaus Zimmermann, zum 1. September 2011 war jedoch genau dies der Fall. (siehe Think-Tank-Corner in ZPB 1/2010 und 2/2010) Die Nachricht erschien nicht nur an prominenter Stelle in den Wirtschaftsteilen der Qualitätspresse, sondern auch auf Seite 1 von BILD. Als Rücktrittsgrund nannte Zimmermann seinen Wunsch, das DIW aus negativen Schlagzeilen um seine Person heraus halten zu wollen. Auch dem Aufsichtsrat unter Leitung des ehemaligen Wirtschaftsweisen Bert Rürup schien das Maß an Negativschlagzeilen spätestens mit dem Abtritt des nur kurz amtierenden DIW-Geschäftsführers erreicht. Der umstrittene Führungsstil Zimmermanns, sowie die Tatsache, dass das DIW bei der Vergabe der prestigeträchtigen Konjunkturprognosen zum zweiten Mal in Folge leer ausging, scheinen die ausschlaggebenden Gründe für den Abtritt des umtriebigen wie umstrittenen Direktors gewesen zu sein, der weiterhin das Bonner Institut zur Zukunft der Arbeit leiten wird. Nicht namentlich genannte DIW-Forscher spekulierten indes in der FAZ vom 2.2.2011 offen darüber, ob die Vorwürfe gegen Zimmermann nicht ein spätes „Revanchefoul“ einer Gruppe um den ehemaligen DIW-Konjunkturchef und heutigen Leiter des IMK, Gustav Horn, gewesen sein könnten. Zimmermann hatte vor einigen Jahren den Vertrag des stark keynesianistisch ausgerichteten Horn am DIW nicht mehr verlängert, was Horn damals als Ausgrenzung seiner nachfrageorientierten wirtschaftspolitischen Position interpretierte.

\section{...und noch ein rot-grünes Strategieinstitut?}

Dass sich im Umfeld von politischen Parteien Think-Tanks gründen, ist in Staaten mit langer Think-Tank-Tradition wie den USA oder Großbritannien nicht ungewöhnlich. Da es in den Deutschland seit mehr als 40 Jahren finanziell sehr gut ausgestattete parteinahe politische Stiftungen gibt, welche die Rolle eines parteinahen Think-Tanks durchaus erfüllen (könnten), galt die Gründung von Think-Tanks durch aktive Parteipolitiker lange als eher unwahrscheinlich. Dies hat sich mittlerweile geändert.

Anfang 2010 gründeten die linken SPD-Mitglieder Andrea Ypsilanti und der im Herbst 2010 verstorbene Hermann Scheer sowie der Ex-Attac-Sprecher und heutige grüne Europaabgeordnete Sven Giegold gemeinsam mit der Linken Katja Kipping das Institut für Solidarische Moderne (ISM). Gemeinsam mit Wissenschaftlern und Angehörigen sozialer Bewegungen sollte das neue Mitgliederinstitut programma- 